\title{
Education of Foreign Children in Poland. Methodical Contexts
}

\begin{abstract}
The aim of the article is to present vital issues related to the school situation of foreign children in Poland. The first part concerns the processes of education and integration of this group of students and legal possibilities to support them. The second one is devoted to the presentation of two (co-written by the author of the article) pedagogical innovations (intercultural portfolio and intercultural tales), which allow us to work with foreigners (kindergarten or first grade) and culturally diverse groups. They serve teaching Polish as a foreign language and forming sensitivity towards otherness.

Poland is a country with a relatively low degree of cultural diversity. Working with foreign students is still a big challenge for the teaching staff. Properly chosen educational methods are an important part of the success of the education and integration of foreign students.

Evaluation studies show that the methods presented in the text, because of their specificity (possibility of an active and creative learning), gained approval of students and teachers, and are effective. They motivate students to learn and share knowledge about their own culture. They can be used in the course of various activities in the area of education. This article is for everyone interested in intercultural education of children.
\end{abstract}

\section{Keywords:}

foreign children, education, integration, pedagogical innovations

Department of Intercultural Education, Faculty of Pedagogy and Psychology, University of Białystok, Poland, E-MAIL: annamlynarczuk@tlen.pl. 


\section{INTRODUCTION}

The space of contemporary Polish education differentiates dynamically due to socio-cultural and migratory movements. Despite transformations in the structure of Polish society, foreign children still constitute a small percentage of all students in formal education system. Poland is thus a country with a small stock of experience with the integration of this group of students. Education of foreign children and supporting them in the process of integration is therefore a big challenge for the teaching staff. Coping with it requires continuous diagnosis of the needs of foreigners and designing methodological solutions adequate to the current needs.

The article is devoted to particular issues related to the education of foreign children in Poland. I assume that choosing appropriate educational methods is an important element of supporting foreign children integration process. In the first part of the article, I analyse selected issues concerning the process of education and integration of foreigners and the legal possibilities of supporting them. The second part of the paper presents two (co-written by the author of the article) innovative educational methods. The methods enable work with foreigners in preschool and school age, as well as culturally diverse groups. The first one (intercultural portfolio method) is for teaching Polish as a foreign language; the second one (intercultural tales method) allows the formation of sensitivity towards otherness and cultural identity.

\section{CHALLENGES OF FOREIGN CHILDREN INTEGRATION WITH POLISH EDUCATION}

Polish schools are attended by children of immigrants who have decided to change their place of residence due to economic and work reasons; those granted refugee status in Poland ${ }^{2}$ or another form of legal protection (e.g., complementary protection) or the ones who are seeking for it. ${ }^{3}$ Polish law allows access to general education for every child residing in Poland - regardless of their legal status. A guarantee of

2 According to the content of Geneva Covenant, foreigners are granted a refugee status due to justified fear of persecution in their country, because of the race, religion, nationality, political opinion or membership in a particular social group and they cannot or do not want to use the protection of that country. For more information see: Covenant Related to the Status of Refugees, signed in Geneva on July 28, 1951, Art. 1; Act on Granting Protection to Foreigners Within the Territory of the Polish Republic from June 13, 2003, Art. 3.

In 2014/15, Polish schools were attended by around 10,000 foreign children, including 800 refugee students; See: J. Suchecka (2015). 
participation in education is an article 70. of Polish Constitution (Dz.U. Nr 78, poz. 483 ze zm., art. 70)4. In addition, the provisions contained in the act of education system (art. 94a, Dz.U. z 2015 r., poz. 2156 oraz z 2016 r. poz. 35, 64 i 195) and the Regulation of the Minister of Education of 9 September 2016 on the education of people who are not Polish citizens and Polish citizens who were educated in other countries [Rozporządzenie MEN z dnia 9 września 2016 r. w sprawie kształcenia osób niebędących obywatelami polskimi oraz osób będących oby watelami polskimi, które pobierały naukę w szkołach funkcjonujących w systemach oświaty innych państw (Dz.U. z 2016 r., poz. 1453)] form the basis of free education for foreigners and take actions to support the process of their integration into the host societies. The foreign students create a diverse and heterogeneous group in terms of cultural affiliation, as well as school and life situation, which are determined by many factors (Markowska-Manista, 2016, pp. 135-140). These include level of knowledge of Polish language, the nature of cultural identity, religious experience acquired in the country of origin, social and economic status (Młynarczuk-Sokołowska, 2016, pp. 150-151). They have a large influence on the process of education and integration of foreigners. Analysis of the literature and own observations suggest that foreign children in the course of education are faced with a number of different problems (Młynarczuk-Sokołowska \& Szostak-Król, 2017, pp. 125-135). The primary barrier that makes it difficult for foreigners to operate in educational institutions and new country of residence is ignorance or low level of knowledge of Polish language. Language is the basic tool for intercultural communication and understanding of the world. The system of language symbols allows formulating thoughts, selfexpression, giving the meanings to human behaviors, observed phenomena, etc. Limitations associated with the proper use of the new language significantly hinder foreigners mastery of curriculum contents and full participation in school life (including establishing peer relations), etc. (Gębal \& Majcher-Legawiec, 2016, pp. 208-209). Another problem is the differences between the programs implemented in their home countries and those which are compulsory in Poland. The discrepancy between the content of education causes rapidly growing school backlogs. Low level of Polish language is a cause of their deepening (Potoniec, 2015, p. 59). Cultural differences also hamper functioning in various school realities. The more the culture of foreign children is different from the dominant culture of the host society, the bigger barrier it can be. In the case of refugee children, additional obstacles to success of the education and integration process are often difficult experiences connected with

According to this Article, everyone has the right to education. Education to the age of 18 is obligatory and free of charge in public schools. 
staying in the home country (e.g., war, loss of a loved one) (Barzykowski et al., 2013, pp. 74-83).

Due to specific circumstances and cultural affiliation, the process of education and integration of children whose parents decided to migrate for profit reasons (e.g., Ukrainian children) ${ }^{5}$ is different than children of refugees (e.g., Chechen children), whose parents left their homeland in fear of losing safety and/or life. The process of entering the circle of a different reality (acculturation) is long and involves the continuous collection of new, sometimes very difficult experiences in all areas of human activity. Acculturation can take many forms and may lead to different results. It entails changes in the value system of behavior and identity. The presented process may result in integration, assimilation, separation or marginalization (GrzymałaMoszczyńska, 2000, pp. 17-25). The most optimal strategy of acculturation is integration, which is a result of the encounter and dialogue between the culture of the newcomers' country and the culture of the host country (Grzymała-Moszczyńska \& Nowicka, 1998, p. 18). Integration is a two-way process that requires commitment and conscious effort from both parts, foreigners as well as the host society. On the level of school education, the integration of foreign students often requires multifaceted support and open attitudes from the teaching staff and peers.

The effectiveness of education and integration of foreign children depends on implementation of measures taken in schools, which will be designed on the basis of reliable diagnoses of foreigners' needs and thus, other members of culturally diverse groups to which they belong. They should assume the individualization of work and program requirements, building positive peer relations, solving current problems of foreign students, etc.

The priority factor for the success of the process of education and integration of foreigners is to develop communication skills in the use of Polish language. It is therefore necessary for people working with foreigners to take actions as soon as possible in order to create favorable conditions for that. Polish educational legislation gives foreigners the possibility of additional free courses of Polish language, ${ }^{6}$ which is organized by the school authority (at the request of management).

Foreigners are also entitled to the assistance of a person using their mother tongue, employed by the school as a teacher's help.? Teacher's help can serve a multi-

5 Among students from Ukraine there are both children of economic migrants and refugees.

6 For more information see: Ustawa z dnia 7 września 1991 r. o systemie... art. 94a, ust. 4, 4a and §18, ust. 1, 2, 3 and Rozporządzenie Ministra Edukacji Narodowej z dnia 9 września 2016 r. w sprawie kształcenia osób niebędących obywatelami polskimi... §18.

For more information see: Ustawa z dnia 7 września 1991 r. o systemie... art. 94a, ust. 4c and Rozporządzenie Ministra Edukacji Narodowej z dnia 9 września 2016 r. w sprawie kształcenia 
faceted support in the course of training foreign students. It may help them understand the contents analyzed in the classroom, mediate communication between foreigners and their parents and teachers, to support the participation in extra-curricular activities (educational activities, school events), etc. In practice, this solution is not used often enough, because of, among others, lack of implementing rules. ${ }^{8}$

It is also vital to support foreign students in terms of equalizing educational disadvantages in order to prevent the deterioration of difficulties at school and exclusion from the education system (Błeszyńska, 2010, pp. 11-13). Without the participation in additional compensatory classes many foreigners will not be able to cope in Polish schools. Polish legislation creates space for organizing additional compensatory classes from subjects taught at school. ${ }^{9}$ These classes can be organized by the school authority when the teacher conducting educational activities in a given subject, considers it necessary to supplement differences in curriculum.

An important factor in developing identity of foreigners, and thus integration, is the knowledge of the mother tongue and their own culture and religion. The results indicate that lack of roots in their own culture constitutes a significant barrier to integration (see more: Grzymała-Moszczyńska \& Nowicka, 1998). It is therefore important to build relationship with what is "own". In the course of formal education, classes for foreigners can be organized in their mother tongue and they may enable learning about their own culture. ${ }^{10}$ These classes can be initiated in consultation with the school, with the consent of the conducting authority, by diplomatic or consular post of country of origin of the foreign children and young people that work in Poland, or non-governmental organization. Moreover, foreign students have the right to religious education. ${ }^{11}$ Religion classes may be held in the inter-group in the catechetica point or in another way.

osób niebędących obywatelami polskimi... §19, ust. 1, 2, 3. Teacher's help is also employed for projects of non-governmental organizations, e.g., Legal Intervention Association, Dialogue Foundation.

8 Rozporządzenie Ministra Edukacji Narodowej z dnia 9 września 2016 r. w sprawie kształcenia osób niebędących obywatelami polskimi... does not specify the provisions of the Act on teacher's help. The responsibilities, education requirements and competences of the teachers' help are not clear. Teachers' help is usually employed as an administrative worker, not educational.

$9 \quad$ See Ustawa z dnia 7 września 1991 r. o systemie... art. 94a, ust. 4c and Rozporządzenia Ministra Edukacji Narodowej z dnia 9 września 2016 r. w sprawie kształcenia osób niebędących obywatelami polskimi... §19, ust. 1, 2, 3.

10 See: Ustawa z dnia 7 września 1991 r. o systemie... art. 94a, ust. 5 and Rozporządzenie Ministra Edukacji Narodowej z dnia 9 września 2016 r. w sprawie kształcenia osób niebędących obywatelami polskimi... §21, ust. 1, 2, 3.

11 For more information see: Ustawa z dnia 7 września 1991 roku o systemie... art. 12, ust. 
According to Polish law, since September 2016 there has been also a possibility of organizing a preparatory unit at school for students who exhibit adaptive difficulties related to cultural differences, the change in the learning environment or disturbances in language communication. ${ }^{12}$ This is a new solution which can be used by schools.

\section{EXEMPLIFICATIONS OF METHODS OF PROMOTING FOREIGN STUDENTS' EDUCATION AND INTEGRATION}

An important factor of a successful process of education and integration of foreign children is the appropriate choice of educational methods. The specificity of the used methods, for example own educational practice, largely determines the motivation and efficiency of foreigners' work. It is also an important part of the acquisition of intercultural communication competence, curriculum contents and building peer relationships (Johnson \& Johnson, 1998, p. 25). Therefore, it is important for the methods to be attractive from the perspective of children and allow the realization of the goals of education.

Two innovative methods of teaching, designed to support education processes and the integration of foreign children, are presented below. They constitute an integral component of educational activities implemented in Poland (the project “Understanding the Other”, program “Adventures of the Other”). The first method (intercultural portfolio) enables teaching Polish as a foreign language in the intercultural context. The second method (intercultural tales) is used while sensitizing the wider otherness and the development of a child's identity. These methods have been recognized by the Podlasie's School Superintendent as pedagogical innovations. ${ }^{13}$ Evaluation studies indicate that these methods, due to their nature, are very popular among Polish teachers and educators, and are attractive and enjoyed by children. They are currently used by institutions involved in education in Poland.

1, 2 and Rozporządzenie Ministra Edukacji Narodowej z dnia 14 kwietnia 1992 roku w sprawie warunków i sposobu organizowania nauki religii w szkołach publicznych, §2, ust. 1, 2, 3, 4, 5.

12 For more information see: Rozporządzenie Ministra Edukacji Narodowej z dnia 9 września 2016 r. w sprawie kształcenia osób niebędących obywatelami polskimi... §17, ust. 4.

13 Podlasie is a region in the north-eastern part of Poland. 


\section{INTERCULTURAL PORTFOLIO METHOD}

The method of intercultural portfolio was established in 2014 in the course of pilot education project Understanding the Other ${ }^{14}$ addressed to foreign children aged $10-12 .{ }^{15}$ Its main aim is to prepare participants to use Polish language, and thus the acquisition of knowledge about Polish culture and socio-cultural realities of life in Poland and the ability to cope with cultural difference.

Assumption of the project is that language is a tool of broadly understood communication and it is used for the analysis of the world, whose structure consists of culturally defined and structured forms and categories. In the context of what is above, the method of intercultural portfolio is intended to develop communicative competence which assumes a close connection between language and culture, in the course of activities concerning Polish language. It is based on systematic documentation of the development of language skills and intercultural experiences in the form of works collected in a folder or binder specially prepared by participants in the learning process. An important element of the method is to monitor and evaluate aspects of own progress in learning the language. ${ }^{16}$ It was developed in relation to European standards for teaching foreign languages included in Common European Framework of Reference for Languages, ${ }^{17}$ assumptions and intercultural communication approach in teaching of foreign languages ${ }^{18}$ and experience (the initiators) gathered in the course of working with foreigners (mainly Chechen nationality). ${ }^{19}$

Proposal of a practical application of the method was included in the scenarios that make up the educational project 'Understanding the Other'. Their contents refer to the author's thematic catalog 'Polish culture and social reality with elements of comparative cultures and social realities of other countries (particularly the countries of participants' origins).'

Work on the basis of project scenarios creates space for the development of intercultural communicative competence, which is necessary in the process of

14 For more information see: A. Młynarczuk-Sokołowska \& K. Szostak-Król (2016).

15 The pilot program was carried out by teachers, educators and students in the Primary School No. 26 and in the Centre for Foreigners.

16 Authors of the method are: Anna Młynarczuk-Sokołowska and Katarzyna Szostak-Król. For more information see: A. Młynarczuk-Sokołowska \& K. Szostak-Król (2016, p. 50).

17 For more information see: Common European Framework of Reference for Languages: Learning, Teaching, Assessment. Retrieved from: https://www.coe.int (accessed: September 5, 2017).

18 For more information see, e.g., P. Garncarek (2006), P.E. Gębal (2010).

19 Experiences gained during work in the Refugee Camp in Białystok, Dialogue Foundation and schools in Podlasie. 
social integration. Contents of classes, contained in scenarios, allow us to learn Polish language in context of learning about cultural diversity of the world. In the course of learning a new language children have possibility to acquire knowledge specific to different cultures and ways of greetings, standards of courtesy; celebrations and family gatherings, religious and national minorities, the role of home and school in the child's life; traditional dishes; various aspects of near and far travel; elements of local history and national symbols. The main part of the course is to acquire knowledge about Polish culture and the realities of life in Poland. Implementation of activities allows the formation of practical communication skills among children, which take into account the cultural aspects of communication (including intercultural differences).

An important element of the project is a group of friends with different, in some cases, complex cultural identities, which takes children into a language journey. It consists of children belonging to Polish majority (Jaś i Marysia), ethnic minority (Tatar) and foreigners (Chechen, Ukrainian, and Vietnamese). They are 'present' during each class during solving tasks and language exercises, as well as during partial and final evaluation of participants' achievements. Therefore, learning Polish language is accompanied by elements of cultural identity and the history of Others, what allowes us to build positive associations with the otherness. After completion of substantive part of the individual classes, every child has the task to evaluate acquired knowledge and skills (using partial evaluation worksheet included in individual intercultural portfolio) and put there work done during class (e.g., drawing with elements of language, handouts). Summary of cycle activities is also enabled by the contained in intercultural portfolio final evaluation sheet and by educational board game proposed by a leading teacher.

Thanks to the intercultural portfolio method, children in the intercultural space, with particular emphasis on different forms of verbal and artistic expression, have the ability to create and collect materials concerning Polish language which are a proof of their deepening multicultural awareness. Contents of scenarios may be the core of classes conducted in groups of different nationalities (including culturally diverse ones) or a source of ideas and inspiration to enrich teachers, educators and volunteers' workshop. Methodological offers included in the scenarios can be used while working with foreigners within the classroom, in extracurricular and nonformal education classes (e.g., language workshops carried out by non-governmental organizations, centers for foreigners, etc.). The evaluation research, ${ }^{20}$ carried out by

20 Evaluation of the project was based on the analysis of children's progress in learning the language (observations during classes, analysis of children's works) and on conversations with the participants. 
teachers and educators who have decided to work using methods of intercultural portfolio, proves the fact that it promotes the development of motivation of children to learn Polish, it brings significant results in terms of the practical use of language, development of intercultural awareness and so on.

Description of the method and lesson plans constituting an integral part of the project Understanding the Other are in the first and in the second edition of the book by Anna Młynarczuk-Sokołowska and Katarzyna Szostak-Król Understanding the Other: Intercultural Communicative Competence in the Process of Teaching Polish as a Foreign Language, Białystok 2014 and 2016, Dialogue Foundation.

\section{INTERCULTURAL TALES METHOD}

Intercultural tales method was developed during the first part of the pilot program Shaping Sensitivity to Differences "Adventures of the Other" and it is its integral part. ${ }^{21}$ Its actions are aimed at children aged 6-9. The theoretical foundation of the program is the Concept of perception of the Other and Interaction with Them by Jerzy Nikitorowicz; ${ }^{22}$ concept of the iceberg in the context of learning about a different identity and culture, ${ }^{23}$ concepts of child development (Lev S. Vygotsky, Erik H. Erikson, etc. $)^{24}$ and the conclusions of the studies on the formation of stereotypes and prejudices among children. ${ }^{25}$

Intercultural tales fit into the canon of psychoeducational fairy tales and at the same time in the educational bibliotherapy. ${ }^{26}$ Intercultural tale is a work addressed to children. Its task is to raise awareness of the differences between people in all areas of human functioning: biological, economic, social and cultural, which are permanently inscribed in every social reality. ${ }^{27}$ The contents of intercultural tales allow children to first understand the right of every individual to make a difference and get to know the problems of functioning as the Stranger and the Other. They

${ }^{21}$ Originators of the project are A. Młynarczuk-Sokołowska and K. Potoniec. The pilot of the first part of the program, devoted mainly to indigenous minorities, was done in 2010 by the teachers, educators and students in kindergartens and schools in Podlasie region. In 2015, the second part of a pilot program that involved foreigners was carried out.

22 For more information see: J. Nikitorowicz (2005, pp. 106-109).

${ }^{23}$ For more information see: Intercultural Learning. T-kit 4 (2000). Strasbourg: Council of Europe, pp. 19-21. Retrieved from: http://pjp-eu.coe.int (accessed: September 1, 2017).

24 For more information see: L.S. Wygotski (1971), E. Erikson (2004).

25 For more information see, e.g.: B. Weigl (1999).

26 For more information see: A. Młynarczuk-Sokołowska, K. Potoniec, \& K. Szostak-Król (2011), A. Młynarczuk-Sokołowska, K. Potoniec, \& K. Szostak-Król (2016).

27 Definition of the intercultural tale was created for the program "Adventures of the Other". For more information see: K. Potoniec (2011, p. 12). 
also offer the opportunity to discover the creative diversity of the world, learn about different cultural elements (e.g., Vietnamese, Armenian, Turkish), develop cognitive curiosity and willingness to interact with the Stranger and the Other.

Implementation of teaching using intercultural tales is not limited only to the transfer of their contents. It assumes the use of the full range of teaching methods (valorising, practical, independent gaining knowledge) that involve all spheres of activity of the child. Working with intercultural tales occures in the following order: classes using intercultural tales, enriched by activating methods and the subsequent strengthening activities aimed at consolidating the knowledge of the previous meeting and expanding it with new related content. During the implementation of the program, the role of an expert (sometimes also the main character) is played by a twelve-year boy named Other. He listens to the confession of characters, he experiences a variety of difficult situations associated with the diversity and he shows the concrete solutions of conflict situations. He is also an authority that shows children the positive aspects of diversity of the world. During the classes, the role of the Other is taken over by a puppet called Other, which participates in every meeting.

Presented model of work creates a space to prepare the child for contacts with Strangers and Others through the acquisition of knowledge about diversity, shaping a positive attitude towards it and working on behavior. It also enables the formation of a child's identity, developing understanding of belonging to a specific group (national, ethnic, religious) and the values it represents. The premise of work with the use of intercultural tales is to develop intercultural sensitivity towards diversity through its influence on: intellect, emotions, behavior, development of social skills and intercultural competence. It assumes learning behavior based on curiosity, principle of tolerance, acceptance and respect for people different from the child. This creates an opportunity for verbal, artistic and kinesthetic expression, encourages active work, independent thinking, using their own knowledge, observation and experience. Extracurricular meetings with the Others - i.e., those belonging to different national, ethnic, etc., groups are the supplements of courses. They give the opportunity for a real encounter with the Others, to go beyond the negative stereotypes and prejudices and create a positive attitude towards diversity through direct interaction. They also create space for the active participation of children's parents.

Implementation of the program was preceded by introductory activities, which beside familiarizing participants with discussed issues and integrating groups, also aimed at initial diagnosis (using drawing and talks) of the Other's image and attitudes towards him. Program finishes with classes that allow us to summarize the acquired knowledge and skills and determine changes in the perception of the Other. 
Evaluation studies indicate ${ }^{28}$ that the classes based on intercultural tales allow children to share their insights and to incorporate elements of their own culture into learning process. Their specificity fosters free and creative action and invites us to reflect on the variety of the surrounding world, diversity, and self-identity. Children are happy to participate in activities. They listen to fairy tales, take part in games and activities, make some artistic works, express their opinions on the topics discussed in class. It happens, among others, thanks to the puppet "Other", to which they quickly become attached. Extracurricular activities which are assumed in the program are, however, the possibility of direct interaction with the Other. They allow children to ask questions, get familiar with other languages and the presence of persons belonging to different cultures, as well as verification of negative stereotypes, prejudices and overcoming the fear of the unknown. Implementation of the program "Adventures of the Other" is a factor of shaping open attitudes among children. Changes in the perception of the Others and their situation, perceiving the potential of diversity in science make positive intercultural relations, etc. ${ }^{29}$

Intercultural tales and lesson plans connected with them were included in the books Adventures of the Other: Tales in Intercultural Education by Anna Młynarczuk-Sokołowska, Katarzyna Potoniec, \& Katarzyna Szostak-Król (Eds.), Białystok 2011, Creativity and Education Foundation, University of Białystok Foundation, and The Adventures of the Other: Intercultural Tales for the Integration of Foreign Children by A. Młynarczuk-Sokołowska, K. Potoniec, \& K. Szostak-Król (Eds.), Białystok 2016, Dialogue Foundation, University of Białystok Foundation.

\section{CONCLUSION}

The situation and the processes of education and integration of foreign students belong to the complex ones. This group of students often struggles with a number of different problems. Settling in a new school and finding themselves in a different socio-cultural reality requires from foreign children developing multiple competencies. It is necessary to compensate the curriculum difference and deficiencies at school. Polish legislation creates the possibility to support foreigners in teaching Polish language, level inequalities at school and develop their own cultural and reli-

${ }^{28}$ Interviews with children related to their participation in the project. For more information see: A. Młynarczuk-Sokołowska (2011).

29 For more information see: A. Młynarczuk-Sokołowska \& K. Szostak-Król (2016a). 
gious identity. An important factor for effective work with foreign students is also the choice of appropriate teaching methods. Our own experiences show that basing on classic and at the same time characteristic of formal education methods often does not work. It is extremely important to use the inclusive, attractive and motivational methods when working with foreigners to encourage them to participate actively in the tasks and to enable them to acquire new knowledge and skills. It is also important that the choice of teaching methods enables foreign students to selfevaluate the progress in the process of learning and experience educational success. The methods presented in this article are examples of methods of this kind.

\section{References}

Barzykowski, K., Grzymała-Moszczyńska, H., Grzymała-Moszczyńska, J., Dzida, D., \& Kosno, M. (2013). Wybrane zagadnienia diagnozy psychologicznej dzieci i młodzieży w kontekście wielokulturowości i wielojęzyczności. Warszawa: Ośrodek Rozwoju Edukacji.

Erikson, E.H. (2004). Tożsamość a cykl życia. Translated by M. Żywicki. Poznań: Wyd. Zysk i S-ka.

Garncarek, P. (2006). Przestrzeń kulturowa w nauczaniu języka polskiego jako obcego. Warszawa: Wydział Polonistyki Uniwersytetu Warszawskiego.

Gębal, P.E. (2010). Dydaktyka kultury polskiej w kształceniu językowym cudzoziemców. Podejście porównawcze. Kraków: TAiWPN Universitas.

Gębal, P.E., \& Majcher-Legawiec, U. (2016). W stronę inkluzji uczniów z doświadczeniem migracyjnym. Nauczanie języka polskiego jako drugiego w świetle rozwoju glottodydaktyki i glottopedagogiki międzykulturowej. In: J. Nikitorowicz, A. MłynarczukSokołowska, \& U. Naimotko (Eds.), Edukacja w warunkach wielokulturowości. Konteksty społeczno-metodyczne (pp. 188-213). Gdańsk: Wydawnictwo Naukowe Katedra.

Grzymała-Moszczyńska, H. (2000). Uchodźcy. Podręcznik dla osób pracujqcych z uchodźcami. Kraków: Zakład Wydawniczy Nomos.

Grzymała-Moszczyńska, H., \& Nowicka, E. (1998). Goście i gospodarze. Problem adaptacji kulturowej w obozach dla uchodźców oraz otaczających je społecznościach lokalnych. Kraków: Zakład Wydawniczy Nomos.

Johnson, D.W., \& Johnson, R.T. (1998). Cultural diversity and cooperative learning. In: W. Putnam (Ed.), Cooperative Learning and Strategies for Inclusion: Celebrating Diversity in the Classroom (pp. 67-85). Baltimore-London-Sydney: Paul H. Bookers Publishing Co.

Markowska-Manista, U. (2016). Praca z uczniem z trudnościami adaptacyjnymi - specyfika różnic kulturowych i zmiany środowiska edukacyjnego. In: E. Śmiechowska-Petrovskij (Ed.), Dzieci z trudnościami adaptacyjnymi w młodszym wieku. Aspekty rozwojowe i edukacyjne w kontekście specyfiki różnic kulturowych (pp. 125-148). Warszawa: Wydawnictwo Naukowe Uniwersytetu Kardynała Stefana Wyszyńskiego.

Młynarczuk-Sokołowska, A. (2011). Inny w bajkach i wśród nas, czyli o uczestnictwie w międzykulturowej edukacji nieformalnej. In: A. Młynarczuk-Sokołowska, K. Potoniec, \& K. Szostak-Król (Eds.), Przygody Innego. Bajki w edukacji międzykulturowej (pp. 14-18). Białystok: Fundacja Edukacji i Twórczości, Fundacja Uniwersytetu w Białymstoku. 
Młynarczuk-Sokołowska, A. (2016). Uczniowie cudzoziemscy w polskiej szkole - problemy, wyzwania i egzemplifikacje działań metodycznych. In: E. Śmiechowska-Petrovskij (Ed.), Dzieci z trudnościami adaptacyjnymi w młodszym wieku szkolnym. Aspekty rozwojowe i edukacyjne w kontekście specyfiki różnic kulturowych (pp. 149-171). Warszawa: Wydawnictwo Naukowe Uniwersytetu Kardynała Stefana Wyszyńskiego.

Młynarczuk-Sokołowska, A., Potoniec, K., Szostak-Król, K. (Eds.) (2016). Przygody Innego. Bajki międzykulturowe na rzecz integracji dzieci cudzoziemskich. Białystok: Fundacja Dialog, Fundacja Uniwersytetu w Białymstoku.

Młynarczuk-Sokołowska, A., \& Szostak-Król, K. (2016a). Dzieci wobec odmienności. In: A. Młynarczuk-Sokołowska, K. Potoniec, \& K. Szostak-Król (Eds.), Przygody Innego. Bajki międzykulturowe na rzecz integracji dzieci cudzoziemskich (pp. 16-30). Białystok: Fundacja Dialog, Fundacja Uniwersytetu w Białymstoku.

Młynarczuk-Sokołowska, A., \& Szostak-Król, K. (2016b). Zrozumieć Innego. Międzykulturowa kompetencja komunikacyjna w procesie uczenia się języka polskiego jako obcego. Białystok: Fundacja Dialog.

Młynarczuk-Sokołowska, A., \& Szostak-Król, K. (2017). Wspieranie uczniów cudzoziemskich ze specjalnymi potrzebami edukacyjnymi w kontekście indywidualizacji pracy i wymagań szkolnych. In: E. Śmiechowska-Petrovskij (Eds.), Dzieci z trudnościami rozwojowymi w młodszym wieku. Indywidualne programy edukacyjno-terapeutyczne w procesie wspierania dzieci (pp. 121-146). Warszawa: Wydawnictwo Naukowe Uniwersytetu Kardynała Stefana Wyszyńskiego.

Nikitorowicz, J. (2005). Kreowanie tożsamości dziecka. Wyzwania edukacji międzykulturowej. Gdańsk: Gdańskie Wydawnictwo Psychologiczne.

Potoniec, K. (2011), Bajki w edukacji międzykulturowej. In: A. Młynarczuk-Sokołowska, K. Potoniec, \& K. Szostak-Król (Eds.), Przygody Innego. Bajki w edukacji międzykulturowej (p. 12). Białystok: Fundacja Edukacji i Twórczości, Fundacja Uniwersytetu w Białymstoku

Potoniec, K. (2015). Integracja uczniów uchodźców w Polskiej szkole. Białystok: Fundacja Dialog, p. 59.

Suchecka, J. (2015). Imigrant brzmi jak obelga. Gazeta Wyborcza, September 23.

Weigl, B. (1999). Stereotypy i uprzedzenia etniczne u dzieci i młodzieży. Studium empiryczne. Warszawa: Wydawnictwo Instytutu Psychologii PAN.

Wygotski, L.S. (1971). Wybrane prace psychologiczne. Translated by E. Flesznerowa, J. Fleszner. Warszawa: Państwowe Wydawnictwo Naukowe.

\section{Online Sources}

Błeszyńska, K. (2010). Dzieci obcokrajowców w polskich placówkach oświatowych - perspektywa szkoły. Raport z badań. Warszawa: Ośrodek Rozwoju Edukacji. Retrieved from: https://www.ore.edu.pl/ (accessed: September 1, 2017).

Common European Framework of Reference for Languages: Learning, Teaching, Assessment. Retrieved from: https://www.coe.int (accessed: September 5, 2017).

Intercultural Learning. T-kit 4 (2000). Strasbourg: Council of Europe. Retrieved from: http:// pjp-eu.coe.int (accessed: September 1, 2017). 


\section{Other Sources}

Covenant Related to the Status of Refugees, signed in Geneva on July 28, 1951.

Konstytucja Rzeczypospolitej Polskiej z dnia 2 kwietnia 1997 r.

Rozporządzenie Ministra Edukacji Narodowej z dnia 9 września 2016 r. w sprawie kształcenia osób niebędących obywatelami polskimi oraz osób będących obywatelami polskimi, które pobierały naukę w szkołach funkcjonujących w systemach oświaty innych państw (Dz.U. z 2016 r., poz. 1453).

Rozporządzenia Ministra Edukacji Narodowej z dnia 14 kwietnia 1992 roku w sprawie warunków i sposobu organizowania nauki religii w szkołach publicznych.

Ustawa o systemie oświaty (Dz.U. z 2015 r., poz. 2156 oraz z 2016 r., poz. 35, 64 i 195).

Ustawa o udzielaniu cudzoziemcom ochrony na terytorium Rzeczpospolitej Polskiej z dnia 13 czerwca 2003 r. 